\title{
First report of a 'Candidatus Phytoplasma trifolii'-related strain (16SrVI-A) associated with white leaf disease in Spirea japonica
}

\author{
Eray Şimşek ${ }^{1}$ • $\cdot$ Hümeyra Ayvacı ${ }^{1} \cdot$ Havva Akkurak $^{1} \cdot$ Murat Dikilitas $^{1} \cdot$ Mehmet Ertuğrul Güldür $^{1}$
}

Received: 28 July 2021 / Accepted: 21 September 2021 / Published online: 25 September 2021

(c) Australasian Plant Pathology Society Inc. 2021

\begin{abstract}
In August of 2018 phytoplasmas naturally infecting Spirea japonica were found in Şanlıurfa province, Turkey and they were identified by nested polymerase chain reaction (PCR), restriction fragment length polymorphism analysis (RFLP) and phylogeny based on sequence analysis. Plants exhibited typical white leaf disease symptoms with reduced leaf size. The phytoplasmas were found to be closely related to 'Candidatus Phytoplasma trifolii' (16SrVI-A). This paper has reported that Spirea japonica is a new host for 'Ca. Phytoplasma trifolii' which is associated with the white leaf disease in S. japonica.
\end{abstract}

Keywords Spirea japonica $\cdot 16$ SrDNA · 'Candidatus Phytoplasma trifolii' · 16SrVI-A subgroup · White leaf disease

\section{Main text}

Spirea japonica is a perennial tree and extensively cultivated in China and Japan. It grows for landscape purposes in various regions of Turkey. In August of 2018, spirea plants exhibiting white leaf disease symptoms with reduced leaf size (Fig. 1) were observed in Şanlıurfa province, Turkey. White leaf disease was previously associated with phytoplasmas in some plant species (Çağlar et al. 2019; Pérez-López and Dumonceaux 2017; Ratchaseema et al. 2021; Song et al. 2016). Phytoplasma-infected Spirea spp. were previously recorded as showing severe stunting, little leaves, and witches' broom symptoms (Bellardi et al. 2018).

DNA was extracted by a spin column-based method (DNeasy plant mini kit, Qiagen) from leaf midribs and stems of five symptomatic and five asymptomatic plants to determine if the symptoms were associated with the phytoplasmas. Universal primers were used for the identification based on PCR of the 16S rDNA gene. The 16S rDNA sequences of the phytoplasmas were firstly amplified by direct PCR using the universal primers R16F1/R0 (Lee et al. 1994) amplifying $1.4 \mathrm{~kb}$ products. The PCR reaction mixture consisted of $1 \mu \mathrm{l}$ template DNA, $1 \mu \mathrm{l}$ of a $10-\mu \mathrm{M}$ primers, $1 \mu \mathrm{l} \mathrm{dNTP} \operatorname{mix}(10 \mathrm{mM}$ of each), $5 \mu \mathrm{l}$

Eray Şimşek

eraysim@harran.edu.tr

1 Agricultural Faculty, Department of Plant Protection, Harran University, Şanlıurfa, Turkey
10X DreamTaq Buffer, 1.25 U DreamTaq DNA Polymerase (Thermo Scientific) and the final volume was adjusted to $50 \mu \mathrm{l}$ with nuclease-free water. PCR conditions were $94^{\circ} \mathrm{C}$ for two min $\left(1\right.$ cycle) and $94^{\circ} \mathrm{C}$ for $30 \mathrm{~s}, 58^{\circ} \mathrm{C}$ for $30 \mathrm{~s}$ (annealing temperature for nested PCR was $55^{\circ} \mathrm{C}$ ) and $72^{\circ} \mathrm{C}$ for 1 min ( 35 cycles) followed by a final extension step at $72^{\circ} \mathrm{C}$ for $5 \mathrm{~min}$. A 1:50-dilution of the direct PCR products was then used as target DNA for nested-PCR using the primer pair R16F2n/R2 (Gundersen and Lee 1996) amplifying $\sim 1.2 \mathrm{~kb}$ products. With this procedure, amplicons of the expected length fragment $(\sim 1.2 \mathrm{~kb}$ in size $)$ were obtained from all the symptomatic samples and the positive control but not from the negative control and asymptomatic plants. Nested-PCR amplicons obtained from the diseased plants were subjected to RFLP analysis by using $A l u \mathrm{I}$, HhaI, HpaII, MseI and RsaI enzymes according to manufacturer instructions (ThermoFisher Scientific). The digestion products were then electrophoresed in $2.0 \%$ agarose gel and visualized with a UV transilluminator. Nested-PCR amplicons gave the same restriction patterns. Thereafter, all nested-PCR amplicons were sequenced in both directions.

The 16S rDNA partial sequences showed $100 \%$ identity with each other. Two representative sequences data were submitted to GenBank and are accessible through the following accession numbers; MZ348974-MZ348975. To classify the sequences, the phylogenetic tree based on nestedPCR amplicons was constructed by MEGA7 (Fig. 2). In silico digestion analysis and determination of subgroups were also performed with the online tool $i$ PhyClassifier 
(Zhao et al. 2009). According to $i$ PhyClassifier, 16S rDNA sequences of the isolates shared $99.80 \%$ similarity with that of the 'Candidatus Phytoplasma trifolii' reference strain (GenBank: AY390261). Wet and virtual RFLP patterns supported each other and the similarity coefficient was 1.00 with the reference pattern of 16SrVI-A (AY390261).

'Candidatus Phytoplasma trifolii' have been previously reported in pears (Usta et al. 2021), pepper (Yilmaz et al. 2019), and cabbage (Serçe and Yılmaz 2019) in Turkey. Spirea spp. infected with diverse phytoplasma subgroups causing stunting including 16SrIII-E from the USA (Griffiths et al. 1994), 16SrI-B from China (Gao et al. 2007), 16SrV-B from China (Li et al. 2010) have been reported. To the best of our knowledge, this is the first report about
Fig. 2 Phylogenetic tree constructed by neighbor-joining method inferred from the 'Candidatus Phytoplasma' species nucleotide sequences of the 16S rDNA gene. The tree shows the relationships among the phytoplasma strains obtained from Spirea japonica plants from Turkey (red squares) and compared with some of 'Candidatus Phytoplasma' species available in GenBank. The tree was constructed using MEGA 7 software. GenBank accession numbers and ribosomal subgroups are reported on the right of the strain names. Acheloplasma laidlawii was employed as outgroup to root the tree

a 'Candidatus Phytoplasma trifolii'-related strain (16SrVIA subgroup) associated with spirea white leaf disease on Spirea japonica in the world. These new findings are of practical significance to the region in terms of the pathogen/ disease epidemiology.
Fig. 1 White leaf disease symptoms in infected Spirea japonica plants (yellow and red arrows show diseased and healthy plants, respectively)

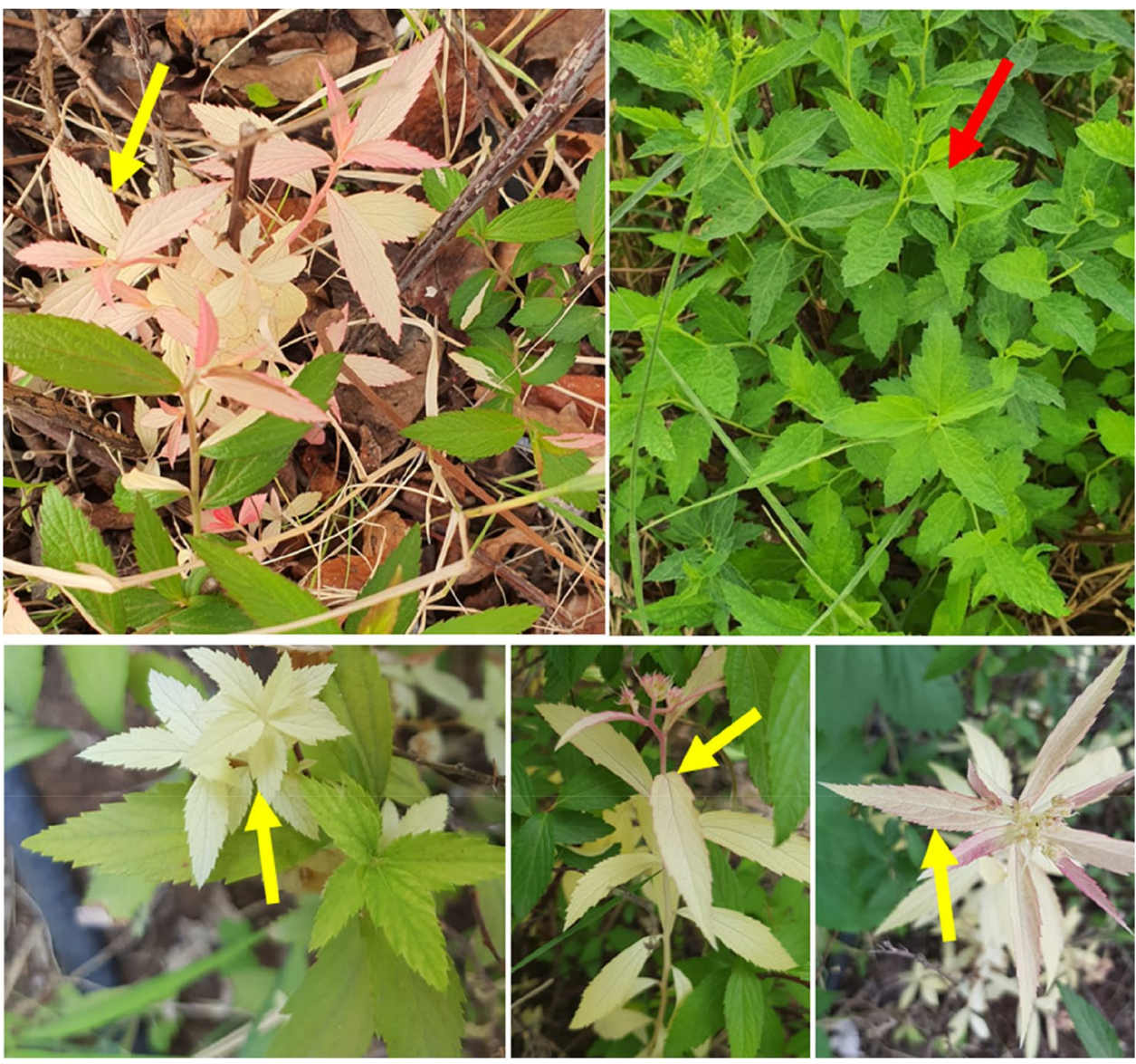




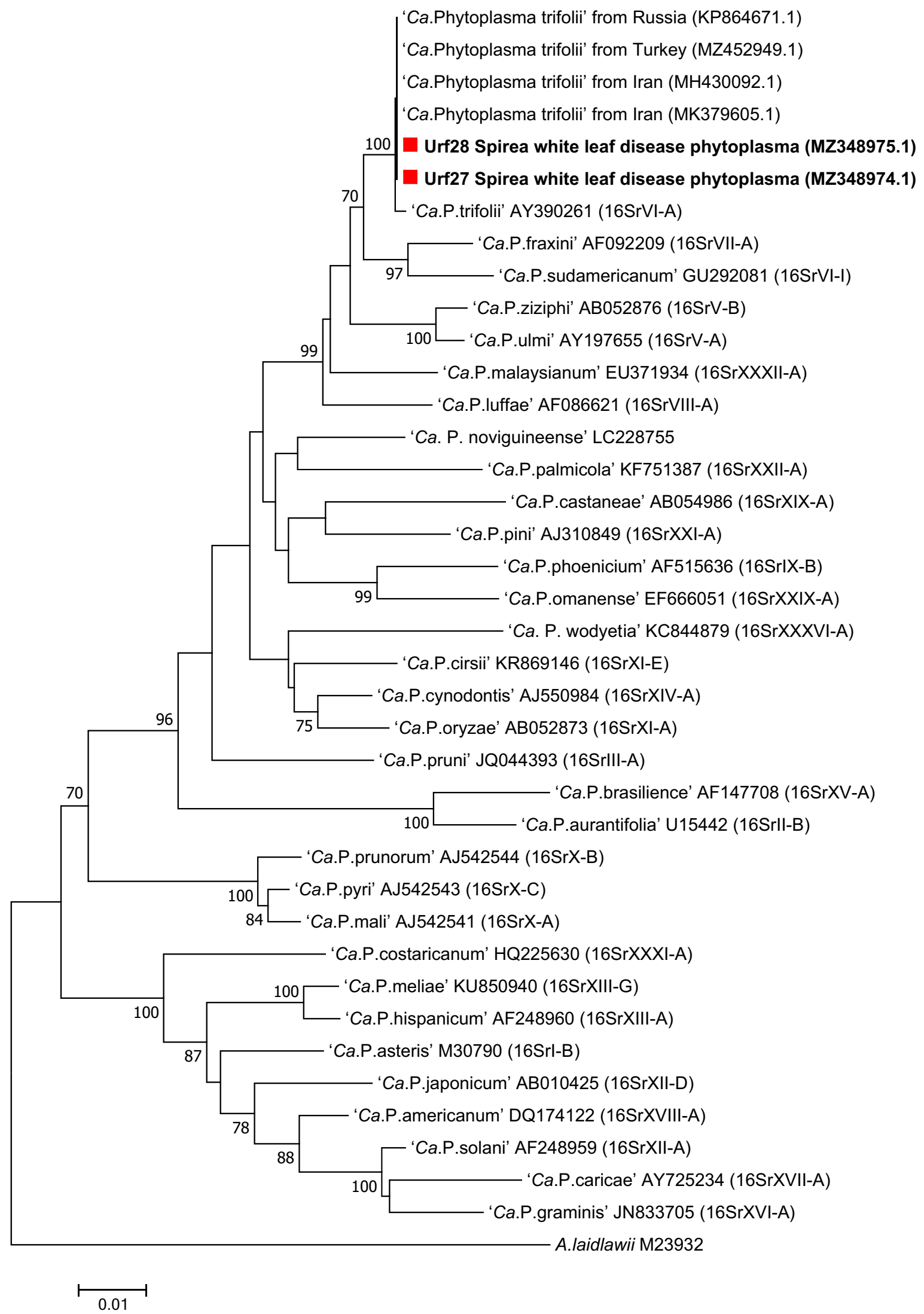


Author contribution EŞ was responsible for designing the NestedPCR and characterization analyses. HA and HA helped the NestedPCR experiments. MEG and ES conducted the field observations and collected samples. MD conducted DNA isolation and phylogenetic studies. ES and MD wrote the manuscript and analysed the data. All authors have read and approved the manuscript.

Data availability statement The data that support the findings of this study are available from the corresponding author upon reasonable request.

\section{Declarations}

Conflict of interest All the authors declare that there is no conflict of interest in this study.

\section{References}

Bellardi MG, Bertaccini A, Madhupriya, Rao, GP (2018) Phytoplasma diseases in ornamental crops. In G. P. Rao, A. Bertaccini, N. Fiore, \& L. W. Liefting (Eds.), Phytoplasmas: Plant Pathogenic Bacteria - I: Characterisation and Epidemiology of Phytoplasma - Associated Diseases (pp. 191-233). Springer, Singapore. https:// doi.org/10.1007/978-981-13-0119-3_7

Çağlar BK, Satar S, Bertaccini A, Elbeaino T (2019) Detection and seed transmission of Bermudagrass phytoplasma in maize in Turkey. J Phytopathol 167(4):248-255. https://doi.org/10.1111/jph. 12792

Gao R, Wang J, Li XD, Zhu XP, Tian GZ (2007) First report of Spirea witches'-broom disease in China. Plant Dis 91(5):635-635. https://doi.org/10.1094/pdis-91-5-0635c

Griffiths HM, Gundersen DE, Sinclair WA, Lee IM, Davis RE (1994) Mycoplasmalike organisms from milkweed, goldenrod, and spirea represent two new 16S rRNA subgroups and three new strain subclusters related to peach X-disease mlos. Can J Plant Path 16(4):255-260. https://doi.org/10.1080/07060669409500728

Gundersen D, Lee I (1996) Ultrasensitive detection of phytoplasmas by nested-PCR assays using two universal primer pairs. Phytopathol Mediterr 35:144-151
Lee IM, Gundersen DE, Hammond RW, Davis RE (1994) Use of mycoplasmalike organism (MLO) group-specific oligonucleotide primers for nested-PCR assays to detect mixed-MLO infections in a single host plant. Phytopathology 84(6):559-566. https://doi.org/ 10.1094/PHYTO-84-559

Li Z, Wu Z, Liu H, Hao X, Zhang C, Wu Y (2010) Spiraea salicifolia: A new plant host of "Candidatus Phytoplasma ziziphi"-related phytoplasma. J Gen Plant Pathol 76(4):299-301. https://doi.org/ 10.1007/s10327-010-0251-4

Pérez-López E, Dumonceaux TJ (2017) Identification of grass white leaf disease associated with a 'Candidatus Phytoplasma asteris' related phytoplasma strain (16SrI-B and cpn60 I-IIIB) in Mexico. Trop Plant Pathol 2017 43(3), 242-246. https://doi.org/10. 1007/S40858-017-0184-Y

Ratchaseema MTN, Kladsuwan L, Soulard L, Swangmaneecharern P, Punpee P, Klomsa-ard P, Sriroth K, Keawsompong S (2021) The role of salicylic acid and benzothiadiazole in decreasing phytoplasma titer of sugarcane white leaf disease. Sci Rep 2021 11(1):1-9. https://doi.org/10.1038/s41598-021-94746-9

Serçe ÇU, Yılmaz S (2019) First report of 'Candidatus Phytoplasma trifolii' (16SrVI group) infecting cabbage (Brassica oleracea) in Turkey. J Plant Pathol 2019 102(2):553-553. https://doi.org/10. 1007/S42161-019-00443-Y

Song H, Wang P, Hou L, Zhao S, Zhao C, Xia H, Li P, Zhang Y, Bian $X$, Wang X (2016) Global analysis of WRKY genes and their response to dehydration and salt stress in soybean. Front Plant Sci 7(FEB2016):9. https://doi.org/10.3389/fpls.2016.00009

Usta M, Güller A, Sipahioğlu HM (2021) First report of "Candidatus Phytoplasma trifolii" associated with leaf reddening and upright growth in pears (Pyrus communis L.). Plant Prot Sci 57(2021)(No. 3):188-195. https://doi.org/10.17221/163/2020-PPS

Yilmaz S, Caglar BK, Djelouah K (2019) Molecular characterization of phytoplasma diseases of pepper in Turkey. J Phytopathol 167(9):479-483. https://doi.org/10.1111/JPH.12820

Zhao Y, Wei W, Lee I-M, Shao J, Suo X, Davis RE (2009) Construction of an interactive online phytoplasma classification tool, iPhyClassifier, and its application in analysis of the peach X-disease phytoplasma group (16SrIII). International Journal of Systemic and Evolutionary Microbiology 59(10):2582-2593. https://doi. org/10.1099/ijs.0.010249-0 